\title{
Assessment of the Consequences of Heat Changes on Cotton Cultivars Growth, Phenology and Yield at Different Sowing Regimes
}

\author{
Kanwar Muhammad Raheel Mehboob ${ }^{1}$, Rashid Iqbal ${ }^{2 *}$, Muhammad Israr ${ }^{3,4}$, Jaweria Shamshad ${ }^{5}$, Umair \\ Riaz $^{6}$, Muhammad Habib-ur-Rahman ${ }^{7,8}$, Fawad Ali', Arif Nawaz ${ }^{10}$, Maliha Sarfraz ${ }^{11}$, Abdul Waheed ${ }^{12}$, \\ Muhammad Tahir Khan ${ }^{13}$ and Muhammad Aslam ${ }^{2}$
}

${ }^{1}$ Department of Agronomy, University of Agriculture Faisalabad, Pakistan; ${ }^{2}$ Department of Agronomy, The Islamia University of Bahawalpur, Pakistan; ${ }^{3}$ Institute of Pure and Applied Zoology, Department of Biochemistry, University of Okara, Pakistan; ${ }^{4}$ College of Life Science, Hebei Normal University, Shijiazhuang, 050024 Hebei, PR China; ${ }^{5}$ College of Earth and Environmental Sciences, University of the Punjab, Lahore; ${ }^{6}$ Soil and Water Testing Laboratory for Research Bahawalpur-6300, Agriculture Department, Government of the Punjab, Pakistan; ${ }^{7}$ Institute of Crop Science and Resource Conservation (INRES) Crop Science Group, University Bonn, Bonn, Germany; ${ }^{8}$ Department of Agronomy, Muhammad Nawaz Shareef University of Agriculture, Multan, Pakistan; ${ }^{9}$ Institute of Chemical Sciences, University of Peshawar, Pakistan; ${ }^{10}$ Department of Chemistry, Bacha Khan University Charsadda, Khyber Pakbtunkhwa, Pakistan; ${ }^{11}$ Institute of Physiology and Pharmacology, University of Agriculture Faisalabad, Pakistan; ${ }^{12}$ Department of Botany, Bacha Khan University Charsadda, Khyber Pakbtunkbwa, Pakistan; ${ }^{13}$ Nuclear Instituteof Agriculture (NLA), Tando Jam, 70060, Pakistan.

\begin{abstract}
Temperature is the main climatic factor that influences the yield just as entire development of farming crops. All periods of phenology of crops are temperature sensitive. Hence, information on appropriate temperature for best yield is significant so as to get maximum production. In current examination, a field test was directed to evaluate the phenology, relative development, ideal sowing time, comparative growth just as yield execution of three cultivars of Bacillus thuringiensis Cotton (Bt. Cotton) at different sowing systems during summer 2015 at cotton research station Regional Agriculture Research Institute Bahawalpur (RARI) Pakistan. The test was directed in an irregular complete block design (RCBD) with a split-plot course of action comprising of three replications. One factor comprised of six planting dates (for example April15 and 30, 15 and 30 May, 14 and29 June) and other factor comprising of three Bt. cotton cultivars (BH-184, MNH-886 and CIM-598). The after effects of the test indicated that both sowing dates and cultivars fluctuated fundamentally for development, phenology and yield. Highst leaf area index (LAI) 4.38, total dry matter (TDM) $1033 \mathrm{~g} \mathrm{~m}^{-2}$, leaf area duration (LAD) 275.6 days and mean harvest development rate $6.51 \mathrm{~g} \mathrm{~m}^{-2}$ day $^{-1}$ were recorded on April 30 sowing. Yield contributing boundaries like opened boll, average boll weight and 100-seed weight altogether shifted and highest seed cotton yield $3847 \mathrm{~kg} \mathrm{ha}^{-1}$ was acquired by cv.MNH-886 when it was planted on April 30.
\end{abstract}

Received | May 24,2019; Accepted | September 10, 2020; Published | October 06, 2020

*Correspondence | Rashid Iqbal, Department of Agronomy, The Islamia University of Bahawalpur, Pakistan; Email: scorpio.rana786@gmail. com

Citation | Mehboob, K.M.R., R. Iqbal, M. Israr, J. Shamshad, U. Riaz, M.H. Rahman, F. Ali, A. Nawaz, M. Sarfraz, A. Waheed, M.T. Khan and M. Aslam. 2020. Assessment of the consequences of heat changes on cotton cultivars growth, phenology and yield at different sowing regimes. Pakistan Journal of Agricultural Research, 33(4): 759-769.

DOI | http://dx.doi.org/10.17582/journal.pjar/2020/33.4.759.769

Keywords | Cultivars, Growth, Phenology, Seed cotton yield, Sowing regimes

\section{Introduction}

$\mathrm{C}$ otton (Gossypium hirsutum L.) is a direct non-food cash yield of the world, comprehensively utilized in cloth producing industries (Iqbal et al., 2019). Additionally, it is widely used for fiber creation and oil extraction. Pakistan is the fourth in the rundown of significant cotton-producing countries and acquires a 
big amount of foreign trade. Cotton assumes a crucial job in the agrarian economy of Pakistan. It includes about $7 \%$ of the incentive in farming and $1.5 \%$ in GDP (Gross Domestic Product) (GoP, 2018). Prior, genetic engineering procedures were utilized to change Bt. Cotton quality extricated from bacteria Bacillus thuringiensis (Bt.). Single protein of this quality is harmful for the biting vermin. Because of obstruction against biting bugs, there might be very nearly a 30\% increase in cotton yield and henceforth additional pay to helpless ranchers. The fundamental point of the Bt. cotton is to abstain from biting vermin assault for example American bollworm, budworm, army and spotted bollworm (GoP, 2018). Sowing time assumes significant job in yield potential (Arshad et al., 2007). Cotton crop is exceptionally receptive to natural conditions and developed in tremendous scope of environmental zones. Numerous elements, for example, the idea of cultivars, planting date, supplements and water the board rehearses plant protection measures are engaged with getting a gainful yield (Ali et al., 2005). Every one of these variables is for the most part influenced by light, soil dampness, moistness and wind speed.

Picking the best sowing time in a specific district is regularly troublesome (Bilal et al., 2019). Too soon and exceptionally late sowing makes the crop helpless to various maladies like cotton leaf curl virus (CLCV) (Nawaz et al., 2019). Thusly, ideal planting time for an assortment in a zone is likewise viewed as a reasonable factor in cotton crops (Bozbek et al., 2006). Low yield of late planted cotton might be credited to the brief term of the flowering stage, all the more shedding of blossoms, pre-experienced blooming and boll shedding and over the top attack of viral infections like CLCV. Seed cotton yield was improved with extending of blossoming period before the beginning of any natural stress and by improving the utilization of dampness and supplements during boll advancement and development stages (Bilal et al., 2019; Ullah et al., 2019). Design of cultivars varies which decides the ideal dispersing required for a cultivar for gainful yield. All out occasional light capture increments with narrow line dividing that possibly increased cotton yield (Steglich et al., 2000).

Short season cultivars are yielding more dry issue than cultivars of long-seasons because of more noteworthy radiation use efficiency (RUE) and light block attempt (Bange and Milory, 2000).
Postponement in plantings from April, the time basic for the plant to create floral buds and blossoms is diminished, because of the hot and long days. This late planting of cotton cultivars influences the shedding power henceforth the last cotton yield (Rahman et al., 2016). Fruiting period is shortened and naximum development time is late because of postponed planting. Be that as it may, following the season, delay planting drives boll improvement into the cooler climate, increase the number of days required from blooming to boll opening. The seed cotton yield enormously dropped in the mid and end June planting dates (Muhammad et al., 2002; Rahman et al., 2018). Any delay in planting time excessively affects boll shedding force and at last seed cotton yield (Tahira et al., 2007).

The motivation behind current investigation is to evaluate the ideal planting time for supportable cotton production in regions of dry atmosphere so as to maintain a strategic distance from hot and cold anxieties. The speculation of the examination was to evaluate phenology, relative development just as yield attributes of three cultivars of Bacillus thuringiensis Cotton (Bt. Cotton) at different sowing times.

\section{Materials and Methods}

A field experiment was conducted at Cotton Research Station, Regional Agricultural Research Institute (RARI), Bahawalpur using randomized complete block design (RCBD) in split-plot arrangements keeping sowing dates (April 15, April 30, May 15, May 30, June 14 and June 29) in main plots and Bt. cotton cultivars (i.e. BH-184, MNH-886 and CIM598) in subplots. In the Bahawalpur region, the study area, sand type is sandy loam whereas climate here is semi-arid. Moreover, no rainfall was observed during the experiment period. Climatic variables (temperature ranges, relative humidity and rainfall) of the experimental area from last five year are given in Table 1. The net plot size was $6 \mathrm{~m} \times 4.2 \mathrm{~m}$ keeping row to row distance of $75 \mathrm{~cm}$ and plant to plant distance of $30 \mathrm{~cm}$. The crop was sown with a seed rate of $20 \mathrm{~kg} \mathrm{ha}^{-1}$. All other standard culture practices such as hoeing, irrigation and plant protection measures were kept for the growing crop. All the state of the art procedures and protocols were carried out to take the required data from the field. Procedure of Gardner et al. (1985) were used to calculate net assimilation rate and leaf area index. 
Table 1: Long term (from last 5 year) climatic data of experimental site.

\begin{tabular}{|c|c|c|c|c|c|c|}
\hline Years & Month & $\begin{array}{l}T_{\max } \\
\left({ }^{\circ} \mathrm{C}\right)\end{array}$ & $\begin{array}{l}\mathrm{T}_{\min } \\
\left({ }^{\circ} \mathrm{C}\right)\end{array}$ & $\begin{array}{l}T_{\text {average }} \\
\left({ }^{\circ} \mathrm{C}\right)\end{array}$ & $\begin{array}{l}\text { RH } \\
(\%)\end{array}$ & $\begin{array}{l}\text { Rainfall } \\
(\mathrm{mm})\end{array}$ \\
\hline \multirow[t]{6}{*}{2011} & April & 38.4 & 23.4 & 30.9 & 66.4 & - \\
\hline & May & 44.9 & 27.3 & 36.1 & 60.2 & 0.4 \\
\hline & June & 48.7 & 31.1 & 40 & 67.3 & - \\
\hline & July & 45.3 & 33.2 & 39.25 & 68.4 & 0.5 \\
\hline & August & 40.8 & 24.6 & 32.7 & 70.5 & - \\
\hline & September & 36.2 & 22.9 & 29.55 & 72.1 & 0.6 \\
\hline \multirow[t]{6}{*}{2012} & April & 39.1 & 29.3 & 34.2 & 62.2 & 0.1 \\
\hline & May & 45.3 & 34.2 & 39.75 & 58.3 & - \\
\hline & June & 52.4 & 36.4 & 44.4 & 55.2 & - \\
\hline & July & 44.3 & 33.7 & 39 & 67.3 & 0.4 \\
\hline & August & 43.2 & 31.2 & 37.2 & 66.1 & - \\
\hline & September & 38.4 & 26.3 & 32.35 & 73.4 & - \\
\hline \multirow[t]{6}{*}{2013} & April & 35.4 & 22.4 & 28.9 & 66.4 & - \\
\hline & May & 45.9 & 28.3 & 37.1 & 60.2 & 0.3 \\
\hline & June & 47.7 & 32.1 & 39.9 & 67.3 & - \\
\hline & July & 44.3 & 34.2 & 39.25 & 68.4 & 0.7 \\
\hline & August & 41.8 & 25.6 & 33.7 & 70.5 & - \\
\hline & September & 37.2 & 21.9 & 29.55 & 72.1 & 0.8 \\
\hline \multirow[t]{6}{*}{2014} & April & 40.1 & 32.3 & 36.2 & 62.2 & 0.3 \\
\hline & May & 46.3 & 33.2 & 39.75 & 58.3 & - \\
\hline & June & 51.4 & 38.4 & 44.9 & 55.2 & - \\
\hline & July & 45.3 & 33.7 & 39.5 & 67.3 & 0.2 \\
\hline & August & 42.2 & 33.2 & 37.7 & 66.1 & - \\
\hline & September & 37.4 & 27.3 & 32.35 & 73.4 & - \\
\hline \multirow[t]{6}{*}{2015} & April & 39.4 & 20.4 & 29.9 & 66.4 & - \\
\hline & May & 46.9 & 28.3 & 37.6 & 60.2 & - \\
\hline & June & 47.7 & 33.1 & 40.4 & 67.3 & - \\
\hline & July & 44.3 & 36.2 & 40.25 & 68.4 & 0.1 \\
\hline & August & 41.8 & 29.6 & 35.7 & 70.5 & - \\
\hline & September & 37.2 & 25.9 & 31.55 & 72.1 & - \\
\hline
\end{tabular}

$T_{\text {max }}$ : maximum temperature; $T_{\text {min }}$ : minimum temperature; $T_{\text {a }}$ average temperature; $R H$ : relative humidity.

\section{Statistical analysis}

The collected data were analyzed statistically by employing Fisher's Analysis of Variance Technique (Steel et al., 1997) and treatment means were compared using Tukey's HSD test at a 5\% probability level.

\section{Results and Discussion}

\section{Phenological parameters}

Number of days from planting to first floral bud initiation: The outcomes in Table 2 demonstrating that the planting date varied fundamentally for first floral bud inception and the maximum number of days (34.78) from planting to first flower bud commencement was recorded for Mid-April planted Bt. Cotton followed by April 30, mid - May, May30, June14 and 29, one by one. These increased April days were because of lower degree day aggregation in April than in May planting. Cultivars additionally altogether fluctuated for first flower bud inception and a higher number of days for a first floral bud (32.44) was recorded in cv. CIM-598 that was measurably at standard with cv. BH-184. The mean value for various long stretches of first botanical bud commencement for various cultivars for example cv. BH-184, cv. MNH-886 and cv. CIM-598 was $31.78,31$ and 32.44 days individually (Table 4). It has been accounted for that temperature was the primary factor for influencing crop improvement and inception of the principal square and its advancement was temperature and cultivar subordinate (Bilal et al., 2019; U1lah et al., 2019). It has been likewise revealed that botanical bud inception and development were influenced by photoperiod and commencement of squaring was utilized for the choice of early genotype (Godoy, 1994). Mid-March and April planting could be refered to a higher number of days for first flower bud inception when contrasted with May planting of cotton (Sarwar et al., 2012). Figure 1 uncovered the powerless positive regression connection $\left(r^{2}=0.54\right)$ between days to first botanical bud inception and seed cotton yield $\mathrm{kg} \mathrm{ha}^{-1}$.

\section{Number of days from planting to very first flower}

The information relevant from days to initial flower as exhibited in Table 2, indicated the Mid April planting required additional days (63.78) from planting to absolute first blossom followed by April 30, May15and 30, June 14 and 29 separately. These additional days required for blossoming in April planting were because of low degree days amassing during April than May and June planting. This appearance of the absolute first blossom was photoperiod subordinate (Sarwar et al., 2012). The essential factor influencing crop advancement was the temperature (Bilal et al., 2019; U1lah et al., 2019). Among cultivars, the thing that matters was minor for a considerable length of time to the primary blossom (Table 4). Sarwar et al. (2012) revealed that mid-March planting took extra days for the primary blossom when contrasted with mid-May planting and days taken to absolute first bloom was not altogether changed with cultivars. 
Table 2: FFBH, NNFB, DFB, DFF, DFBO, BMP, LAI, LAD, TDM, CGR and NAR as affected by sowing dates and cultivars.

\begin{tabular}{|c|c|c|c|c|c|c|c|c|c|c|c|}
\hline Treatment & FFBH & NNFB & DFB & DFF & DFBO & BMP & LAI & LAD & TDM & CGR & NAR \\
\hline \multicolumn{12}{|c|}{ Sowing dates } \\
\hline 15-Apr & $24.96 \mathrm{~A}$ & $9.71 \mathrm{~A}$ & $34.78 \mathrm{~A}$ & $63.78 \mathrm{~A}$ & $111.11 \mathrm{~A}$ & $47.3 \mathrm{~A}$ & $4.15 \mathrm{AB}$ & $264.70 \mathrm{AB}$ & $1073.5 \mathrm{~A}$ & 5.98 & $3.62 \mathrm{BC}$ \\
\hline 30-Apr & $24.22 \mathrm{AB}$ & 9.07AB & $33.89 \mathrm{AB}$ & $62.44 \mathrm{AB}$ & 106.33B & $43.9 \mathrm{AB}$ & $4.38 \mathrm{~A}$ & $275.86 \mathrm{~A}$ & $1033.99 \mathrm{~A}$ & 6.51 & $3.84 \mathrm{AB}$ \\
\hline 15-May & $23.91 \mathrm{ABC}$ & 8.53ABC & $31.78 \mathrm{ABC}$ & $61.44 \mathrm{~B}$ & $101.78 \mathrm{C}$ & $40.3 \mathrm{BC}$ & $3.87 \mathrm{BC}$ & $263.83 \mathrm{AB}$ & 901.93B & 5.92 & $3.96 \mathrm{~A}$ \\
\hline 30-May & $23.44 \mathrm{BC}$ & 7.76BCD & $30.78 \mathrm{BC}$ & $59.33 \mathrm{BC}$ & $97.56 \mathrm{D}$ & $38.2 \mathrm{BC}$ & $3.64 \mathrm{CD}$ & 244.31B & $840.18 \mathrm{~B}$ & 5.51 & $3.31 \mathrm{CD}$ \\
\hline 14-Jun & $22.91 \mathrm{C}$ & $7.58 \mathrm{CD}$ & $29.78 \mathrm{C}$ & $55.80 \mathrm{CD}$ & $93.00 \mathrm{E}$ & $37.2 \mathrm{C}$ & $3.55 \mathrm{D}$ & $216.8 \mathrm{C}$ & 783.49B & 5.32 & $3.18 \mathrm{D}$ \\
\hline 29-Jun & $22.82 \mathrm{C}$ & $7.16 \mathrm{D}$ & $29.44 \mathrm{C}$ & $52.80 \mathrm{D}$ & $87.67 \mathrm{~F}$ & $34.9 \mathrm{C}$ & $3.48 \mathrm{D}$ & $197.67 \mathrm{C}$ & $726.76 \mathrm{C}$ & 5.19 & $3.15 \mathrm{D}$ \\
\hline HSD\% & 1.16 & 1.36 & 3.851 & 4.411 & 2.808 & 6.017 & 0.439 & 23.86 & 99.745 & 0.301 & 0.325 \\
\hline \multicolumn{12}{|l|}{ Cultivars } \\
\hline BH-184 & 23.87 & 8.22 & $31.77 \mathrm{AB}$ & 60.01 & 100.50 & 40.5 & $3.86 \mathrm{~A}$ & $243.2 \mathrm{AB}$ & $893.59 \mathrm{~A}$ & 5.76 & 3.56 \\
\hline MNH-886 & 23.52 & 8.36 & $31.00 \mathrm{~B}$ & 59.39 & 99.22 & 39.8 & $4.00 \mathrm{~A}$ & $251.93 \mathrm{~A}$ & $927.58 \mathrm{~A}$ & 5.89 & 3.52 \\
\hline CIM-598 & 23.74 & 8.31 & $32.44 \mathrm{~A}$ & 58.40 & 99.00 & 40.6 & $3.68 \mathrm{~B}$ & $236.46 \mathrm{~B}$ & $858.78 \mathrm{~B}$ & 5.56 & 3.45 \\
\hline HSD\% & ns & ns & 1.209 & ns & ns & ns & 0.287 & 11.18 & ns & 0.05 & $\mathrm{~ns}$ \\
\hline
\end{tabular}

Means sharing different letters differ significantly at $p \leq 0.05$. Significant changes are highlighted by an asterisk $(*) ;{ }^{*} P \leq 0.05,{ }^{* *} P \leq 0.01$; ns: non-significant; "FFBH: First fruiting branch height $(\mathrm{cm})$; NNFB: node number from first fruiting branch; DFB: Days taken to first floral bud initiation; DFF: Days taken to first flower; DFBO: Days taken to first boll opening; BMP: Boll maturation period (days); LAI: Leaf area index; LAD: leaf area duration (days); TDM: total dry matter (g); CGR: crop growth rate ( $\mathrm{g} \mathrm{m}^{-2}$ day ${ }^{-1}$ ); NAR: Net assimilation rate $\left(g m^{-2} d a y^{-1}\right)$.

Table 3: Plant height, sympodial, monopodial, opened bolls, average boll weight, 100-seed weight, seed cotton yield and Ginning out turn as affected by sowing dates and cultivars.

$\begin{array}{lllllllll}\begin{array}{l}\text { Treatment } \\ \text { Sowing dates }\end{array} & \text { PH } & \text { Sympod } & \text { Monopod } & \text { O.B } & \text { ABW } & \text { 100-SW } & \text { S.C.Y } & \text { GOT\% } \\ \text { 15-Apr } & 142.87 \mathrm{~A} & 23.84 \mathrm{AB} & 2.47 & 35.2 \mathrm{~A} & 2.81 \mathrm{~B} & 6.78 & 3265.83 \mathrm{AB} & 39.03 \mathrm{AB} \\ \text { 30-Apr } & 131.73 \mathrm{~B} & 25.49 \mathrm{~A} & 2.49 & 39.4 \mathrm{~A} & 2.78 \mathrm{~B} & 6.94 & 3681.09 \mathrm{~A} & 39.46 \mathrm{~A} \\ \text { 15-May } & 124.04 \mathrm{C} & 23.20 \mathrm{AB} & 2.56 & 35.2 \mathrm{AB} & 2.85 \mathrm{AB} & 7.17 & 3310.83 \mathrm{~A} & 39.54 \mathrm{~A} \\ \text { 30-May } & 107.78 \mathrm{D} & 20.67 \mathrm{BC} & 2.49 & 30.9 \mathrm{BC} & 2.86 \mathrm{AB} & 6.65 & 2871.62 \mathrm{~B} & 38.57 \mathrm{AB} \\ \text { 14-Jun } & 98.16 \mathrm{E} & 18.84 \mathrm{CD} & 2.53 & 27.8 \mathrm{CD} & 2.91 \mathrm{~A} & 7.21 & 2236.64 \mathrm{C} & 37.90 \mathrm{AB} \\ \text { 29-Jun } & 88.47 \mathrm{~F} & 15.73 \mathrm{D} & 2.40 & 26.4 \mathrm{D} & 2.82 \mathrm{AB} & 6.84 & 1850.98 \mathrm{C} & 37.38 \mathrm{~B} \\ \text { HSD\% } & 5.64 & 3.813 & \mathrm{~ns} & 4.315 & 0.09 & n s & 438.37 & 2.07 \\ \text { Cultivars } & & & & & & & & \\ \text { BH-184 } & 116.40 \mathrm{~A} & 21.42 & 2.57 \mathrm{~A} & 32.1 \mathrm{~B} & 2.85 \mathrm{~B} & 7.04 \mathrm{~A} & 2867.85 \mathrm{AB} & 38.68 \mathrm{~A} \\ \text { MNH-886 } & 117.74 \mathrm{~A} & 21.92 & 2.62 \mathrm{~A} & 34.1 \mathrm{~A} & 2.89 \mathrm{~A} & 7.24 \mathrm{~A} & 3040.11 \mathrm{~A} & 39.47 \mathrm{~A} \\ \text { CIM-598 } & 112.37 \mathrm{~B} & 20.54 & 2.28 \mathrm{~B} & 31.2 \mathrm{~B} & 2.78 \mathrm{C} & 6.52 \mathrm{~B} & 2700.54 \mathrm{~B} & 37.79 \mathrm{~B} \\ \text { HSD\% } & 2.24 & \mathrm{~ns} & 0.24 & 1.631 & n s & 0.41 & 221.35 & 0.89\end{array}$

Means sharing different letters differ significantly at $p \leq 0.05$. Significant changes are bighlighted by an asterisk (*); $P \leq 0.05 ;{ }^{* * *} P \leq 0.01$; ns, non-significant; "PH: plant height (cm); Sympod: sympodials; monopod: monopodials; O.B: opened boll; ABW: Average boll weight (g); 100-SW: 100-seed weight (g); S. C.Y: Seed cotton yield ( $\left.\mathrm{kg} \mathrm{ha}^{-1}\right)$ and GOT\%: Ginning out turn.

Figure 1 uncovered the solid positive regression relation $\left(r^{2}=0.82\right)$ between days taken to initially bloom and seed cotton yield $\mathrm{kg} \mathrm{ha}^{-1}$.

Number of days from planting to first boll opening

From the perception in Table 2, it is clarified that 15 April planting needs more number of days (111.11) from planting to first boll opening than other planting dates. The higher number of days taken to boll opening in April planting was because of low degree day aggregation during April when contrasted with May and June planting. Cultivars demonstrated insignificant results (Table 4). Early developing cultivars opened their boll sooner than late-developed 
cultivars (Panhwar et al., 2002). Mid-March and April planting indicated more bolls from planting to first boll opening when contrasted with May planting and cultivars was not essentially differed for the quantity of days taken from planting to first boll opening (Sarwar et al., 2012). Figure 1 uncovered the solid positive regression relation $\left(r^{2}=0.77\right)$ between days taken to first boll opening and seed cotton yield $\mathrm{kg}$ ha-1.

\section{Boll maturation period (days)}

From the information given in Table 2, it is uncovered that very boll development length significantly fluctuated with various planting dates while cultivars and collaboration discovered undistinguished. Maximun number of days (47.3) for boll development was recorded on April15 planting of cotton followed by April 30, May15and 30, June 14 and 29 individually. Sarwar et al. (2012) additionally found that cultivars and its connection demonstrated negligible outcomes and mid-March planting dates required additional days for boll development when contrasted with May planting. It has been accounted for that boll size and boll development period diminished as temperature increased (Reddy et al., 1999). Shrinking of bolls because of temperature brings about quick development. Figure 1 uncovered the positive regression realtion $\left(\mathrm{r}^{2}=0.59\right)$ between boll development and seed cotton yield $\mathrm{kg} \mathrm{ha}^{-1}$ (Table 4).
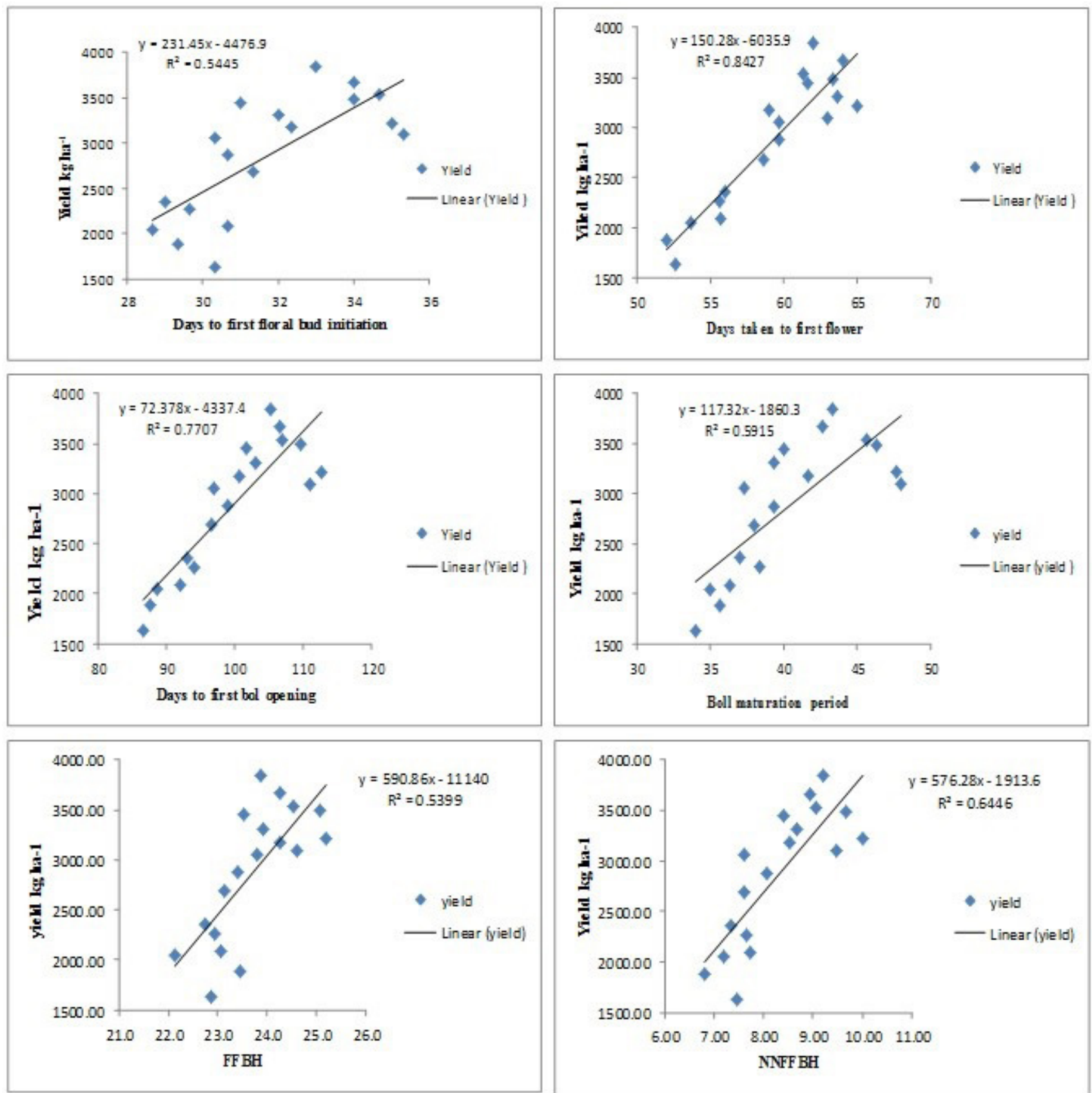

Figure 1: Relationship of seed cotton yield with First fruiting branch height, node number from the first fruiting branch, days to first floral bud, days to first flower initiation, days to first boll opening and boll maturation period. 

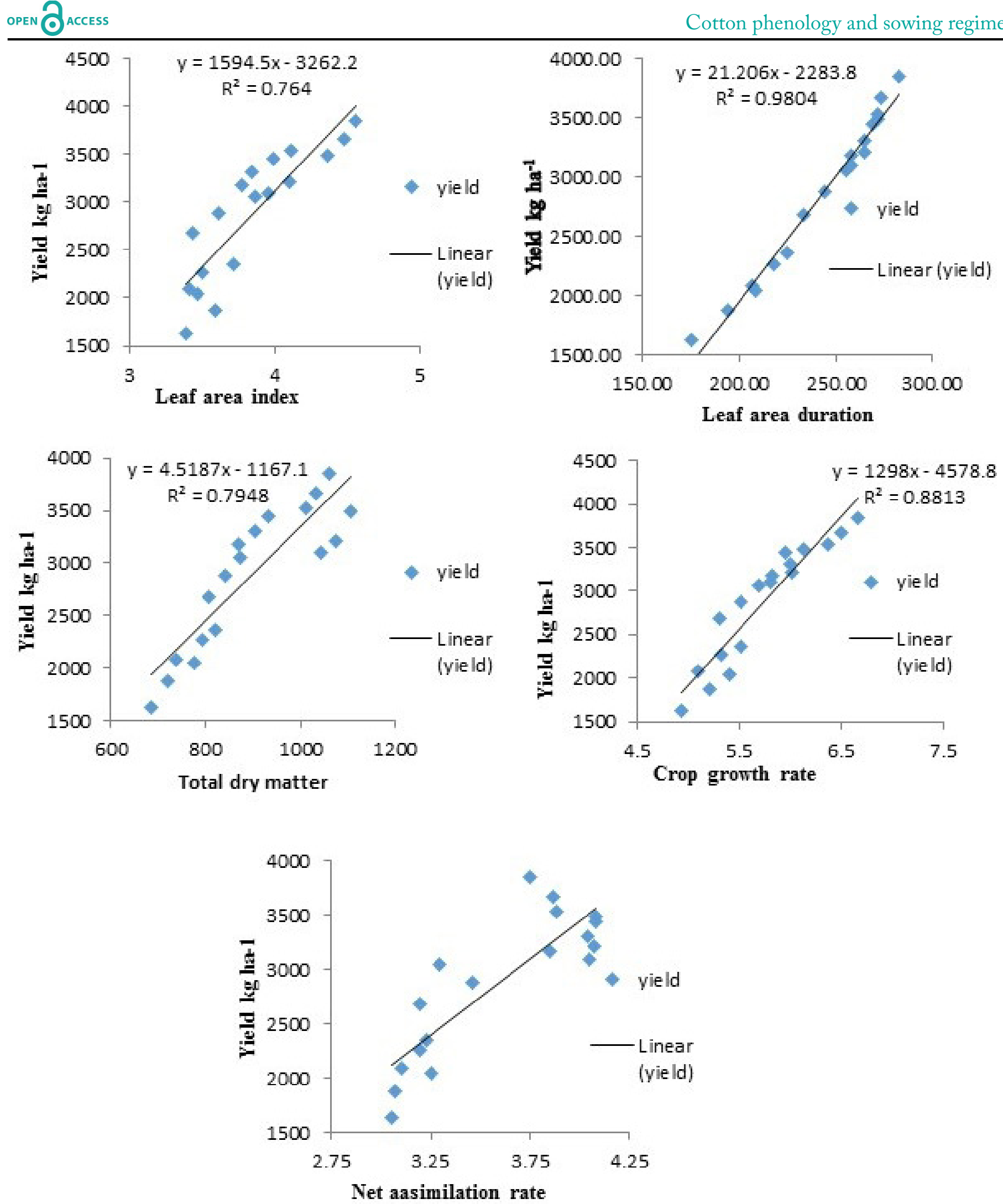

Figure 2: Relationship of leaf area index, leaf area duration, Total dry matter, Crop growth rate and net assimilation rate with Seed cotton yield.

Growth parameters

Leaf area index: Leaf area index is the fundamental physiological determinant of crop development and yield. Information introduced in Table 2 indicated that LAI fundamentally shifted during the season at various planting dates and cultivars. Highest LAI approached the estimation of (4.38) of April 30 planting. While for another situation of cultivars greatest LAI (4.00) was seen in cv. MNH-886 followed by cv. BH-184 and cv. CIM-598. Arshad et al. (2007) likewise revealed that LAI changed essentially at various planting dates and cultivars. 
Fig.2 uncovered the solid positive regression relation $\left(\mathrm{r}^{2}=0.76\right)$ between leaf area index and seed cotton yield $\mathrm{kg} \mathrm{ha} \mathrm{h}^{-1}$. Due to rise in temperature speed of cell division is stifled so development of leaf is checked outcomes, which at last prompts decline in leaf area index (Table 4).

\section{Total dry matter $\left(\mathrm{g} \mathrm{m}^{-2}\right)$}

The information interpreted in Table 2, exhibit that complete dry matter is clearly influenced by various planting dates and cultivars. On account of planting dates most extreme TDM $\left(1073.5 \mathrm{gm}^{-2}\right)$ was seen of April 15 planting. TDM was fundamentally changed with cultivars and most extreme TDM (927.58 g m-2) was seen in cv. MNH-886 followed by cv. BH-184 and cv. CIM-598. Bilal et al. (2019) and Ullah et al. (2019) saw that all out dry matter was fundamentally shifted with planting dates and cultivars and their connection likewise demonstrated enormous outcomes. Iqbal (2010) observed that complete dry matter amazingly changed with various planting dates and cultivars and early planting have more absolute dry matter aggregation. Figure 2 uncovered the solid positive regression relation $\left(\mathrm{r}^{2}=0.79\right)$ between all out dry issue and seed cotton yield $\mathrm{kg} \mathrm{ha}^{-1}$. Leaf area index which is in this manner subject to temperature likewise influence complete dry matter. Lower the leaf area index lower is the complete dry matter.

\section{Leaf area duration (days)}

The experimental values in Table 2, indicating that leaf area duration quite fluctuated at various planting dates and cultivars while the connection was found non-critical. Highest LAD (275.86) was observed in 30 April planting of cotton. The mean estimation of the leaf area span at various planting dates for example April 15 and 30, May 15 and 30, June 14 and 29 was $264.70,275.86,263.83,244.31,216.8$ and 197.67 individually. Most extreme LAD was seen in MNH-886 followed by BH-184 and CIM-598. The mean estimation of leaf area span for cultivars for example BH-184, MNH-886 and CIM-598 were 243.2, 251.93 and 236.46, individually. Another investigation revealed that the LAD of cotton crops changed essentially with various planting dates and cultivars (Arshad et al., 2007). He saw that early planting demonstrated more leaf area span when contrasted with the late planting of cotton. This is a direct result of ideal temperature and expanded number of developing days. The higher temperature invigorates quick fruition of vegetation cycle. Figure
2 uncovered the solid positive regression relation $\left(r^{2}=0.98\right)$ between leaf region span and seed cotton yield $\mathrm{kg} \mathrm{ha} \mathrm{h}^{-1}$. It unmistakably portrays the reliance of cotton yield on leaf area index.

\section{Crop growth rate (g $\mathrm{m}^{-2}$ day $\left.^{-1}\right)$}

The crop development rate is on the basic pointer of development during various time cuts of the yield season. Perceptions in Table 2 clarify that the relation of planting dates and cultivars for mean CGR was critical. Highest mean CGR was seen in $\mathrm{MNH}-$ 886 (6.65gm-2day-1) at April 30 planting of cotton followed by BH-184 and CIM-598 separately. Iqbal (2010) detailed that mean CGR was essentially influenced by planting dates and cultivars and their interactions. He additionally found that early planting had indicated a higher estimation of mean CGR when contrasted with the late planting of cotton. Figure 2 uncovered the solid positive regression relation $\left(r^{2}=0.88\right)$ between crop development rate and seed cotton yield $\mathrm{kg} \mathrm{ha}{ }^{-1}$ which was additionally announced by Iqbal (2010). Ideal temperature favors increased growth rate of cotton and supports the planting of the harvest at the ideal time (Table 4).

\section{Net assimilation rate $\left(g \mathrm{~m}^{-2}\right.$ day $\left.{ }^{-1}\right)$}

The information presented in Table 2, advising that the net integration rate apparently varied at various planting dates while cultivars and association were discovered unremarkable. The highest estimation of NAR (3.96gm-multi/day) was watched on May 15 planting of Bt. cotton followed by April 30 and 15, May 30, June 14 and 29 while least NAR (3.15 g $\mathrm{m}$-multi day-1) was seen on June 29 planting of Bt. Cotton. It has been accounted for that NAR scarcely changed with various planting dates and cultivars (Arshad et al., 2007). Bilal et al. (2019) found that the individual and joint impact of planting dates and cultivars for net absorption rate was minor. Figure 2 uncovered the solid positive regression relation $\left(r^{2}=0.72\right)$ between net incorporation rate and seed cotton yield $\mathrm{kg} \mathrm{ha}^{-1}$ (Table 4).

\section{Yield related parameters}

Plant height (cm): It is discovered from the information in Table 3 that plant tallness influenced essentially by various planting dates and cultivars while interaction indicated insignificant outcomes (Table 5). Maximum plant height $(142.87 \mathrm{~cm})$ was seen of April 15 while least plant height $(88.47 \mathrm{~cm})$ was recorded of June 29 sowing of Bt. Cotton, while on account 
of cultivars, highest plant height $(117.74 \mathrm{~cm})$ was seen in MNH-886 that was measurably at standard with $\mathrm{BH}-184$. It has been seen that early planting of cotton demonstrated most extreme plant height than the late planting of cotton because of a more drawn out term accessible for the solid development of cotton crop (Bilal et al., 2019). Cotton plant height was influenced by various cultivars and indicated critical outcomes that were comparative and have been accounted for by (Ehsan et al., 2008; Bilal et al., 2019). Growth potential and yield of cultivars relies upon the genetic makeup of the cotton cultivars.

\section{Number of plants per plot}

The information from Table 3, showing that the intuitive impact of planting dates and cultivars have a significant outcome. At early planting, every variety demonstrated more number of plants per plot when contrasted with late planting. On April 15, planting maximum number of plants 103.3 was seen with MNH-886 and at 29 June less number of plants (68) was seen in CIM-598. It has been accounted for that various plants per plot demonstrated significant contrasts (Table 5) among both planting dates and cultivars and these outcomes were steady with the discoveries of Arshad et al. (2007). Early planting favors the plant germination and formative help. Along these lines, plants had more appropriate time in less harsh atmosphere in early planting. While in late planting, plants couldn't grow and stand well in harsh temperature condition.

\section{Number of monopodial branches per plant}

The data laid out in in Table 3, shows that monopodial branches changed essentially by various cultivars while planting dates and cooperation was found non-significantly. Among three cultivars MNH-886 produced the most extreme number of monopodial branches (2.63) that is factually at standard with BH-184 while CIM-598 delivered a base number of monopodial branches (2.23). It has been accounted for that the quantity of monopodial branches was altogether influenced by various cultivars (U1lah et al., 2019; Bilal et al., 2019; Sarwar et al., 2012).

\section{Number of sympodial branches per plant}

The indicated values in Table 3, clarify that number of sympodial branches altogether contrasted by various planting dates while assortments and interaction were found non-critical. The maximum estimation of sympodial branches saw on $30^{\text {th }}$ April planting of that was factually at standard with 15 April and 15 May planting of Bt. Cotton while least sympodial branches were recorded on June 29, planting. It has been accounted for that early planting of cotton in March and April delivered more sympodial branches than late planting because of ideal temperature at early development phases of cotton (Ullah et al., 2019; Bilal et al., 2019).

\section{Opened bolls number per plant}

From the given information in Table 3 , it is seen that planting dates and cultivars significantly affect the number opened of bolls per plant of cotton while the connection was found non-significant. Most extreme opened bolls were seen in 30 April planting of cotton because of ideal natural conditions followed by April 15, May 15 and 30, June 29 and 14, individually. The mean an incentive for the quantity of opened bolls per plant of cotton at various planting dates was 35.2,39.37, $35.15,30.88,27.78$ and 26.43 separately. Arshad et al. (2007) detailed that early planting of cotton delivered more number of opened bolls that was because of ideal natural condition. The mean an incentive for opened of bolls per plant for various cultivars for example MNH886, BH-184 and CIM-598 were 34.08, 32.13 and 31.19, individually. Bilal et al. (2019) and Ullah et al. (2019) likewise saw that the quantity of opened bolls per plant essentially varied by cultivars.

\section{Average boll weight (g)}

Table 3 shows that highest boll weight was seen on June14 followed by May 30 and 15, June 29, April 15 and 30 respectively. The mean estimation of normal boll weight for various planting dates was (2.81, $2.78,2.85,2.86,2.91$ and 2.82) separately. While, on account of cultivars normal boll weight quite differed (Table 5). The most extreme boll weight was recorded with MNH-886 followed by BH-184 and CIM-598. The mean an incentive for cultivars for example $\mathrm{BH}$ 184, MNH-886 and CIM-598 were $(2.85,2.89$ and 2.78). It has been accounted for that season assumes a significant role in cotton production and uncommonly boll weight and results indicated that maximum boll weight was gotten between $1^{\text {st }}$ May to 15 June planting of cotton while early and late planting of cotton decreased boll weight (Rahman et al., 2019). It has been accounted for that the boll weight of cotton plants was fundamentally varied with various cultivars because of various genetic makeups. These outcomes were like the discoveries of (Hebbar et al., 2007; Arshad et al., 2007). 
Table 4: Analysis of variance of FFBH, NNFB, DFB, DFBO, BMP, LAI, LAD, TDM, CGR and NAR.

$\begin{array}{lllllllllllll}\text { SOV } & \text { DF FFBH } & \text { NNFB } & \text { DFB } & \text { DFF } & \text { DFBO } & \text { BMP } & \text { LAI } & \text { LAD } & \text { TDM } & \text { CGR } & \text { NAR } \\ \mathrm{Rep} & 2 & 0.5511 & 1.4044 & 9.148 & 1.59 & 42.48 & 57.37 & 0.2991 & 126.3 & 208613 & 0.0279 & 0.04248 \\ \mathrm{Sd} & 5 & 30.1600^{* *} & 42.8511^{* * *} & 215.037^{*} & 805.26^{* *} & 3354.54^{* *} & 948.76^{* * *} & 5.7934^{* *} & 42504.3^{* *} & 854774^{* *} & 10.9381^{* *} & 5.40451^{* *} \\ \begin{array}{l}\text { Error Rep } \\ \times \mathrm{Sd}\end{array} & 10 & 5.0222 & 6.9378 & 55.519 & 72.85 & 29.52 & 135.52 & 0.7219 & 2135.3 & 37236 & 0.1302 & 0.39641 \\ \mathrm{Cv} & 2 & 1.0978^{\text {ns }} & 0.1911^{\text {ns }} & 18.815^{*} & 23.81 & 23.59^{\text {ns }} & 6.37^{\text {ns }} & 0.8884^{*} & 2166.2^{* *} & 42069^{*} & 1.0095^{* *} & 0.10618^{\text {ns }} \\ \mathrm{Sd} \times \mathrm{Cv} & 10 & 4.5022^{\text {ns }} & 1.7644^{\text {ns }} & 1.185^{\text {ns }} & 33.96 & 24.41^{\text {ns }} & 38.52^{\text {ns }} & 0.2675^{\text {ns }} & 240.8 & 2775^{\text {ns }} & 0.1172^{*} & 0.18831^{\text {ns }} \\ \begin{array}{l}\text { Error Rep } \\ \times \text { Sd } \times \text { C }\end{array} & 24 & 9.2800 & 13.0311 & 50.667 & 190.89 & 366.670 & 663.11 & 2.8576 & 4328.2 & 63727 & 0.1170 & 0.66424 \\ \text { Total } & 53 & 50.6133 & 66.1800 & 350.370 & 1128.37 & 3841.20 & 1849.65 & 10.8279 & 51501.4 & 1209735 & 20849.4 & 6.80213\end{array}$

Means sharing different letters differ significantly at $p \leq 0.05$. Significant changes are highlighted by an asterisk $\left(^{*}\right) ;{ }^{*} P \leq 0.05,{ }^{* * *} P \leq 0.01 ;$; n, non-significant. "FFBH: First fruiting branch height (cm); NNFB: node number from first fruiting branch; DFB: Days taken to first floral bud initiation; DFF: Days taken to first flower; DFBO: Days taken to first boll opening; BMP: Boll maturation period (days); LAI: Leaf area index; LAD: leaf area duration (days); TDM: total dry matter (g); CGR: crop growth rate ( $\mathrm{g} \mathrm{m}{ }^{-2}$ day $\left.{ }^{-1}\right)$; NAR: Net assimilation rate (g $m^{-2}$ day $\left.^{-1}\right)$.

Table 5: Analysis of variance of plant height, sympodial, monopodial, opened boll, average boll weight, 100-seed weight, seed cotton yield and ginning outturn.

$\begin{array}{llllllllll}\text { SOV } & \text { DF } & \text { PH } & \text { Sympod } & \text { Monopod } & \text { O.B } & \text { ABW } & \mathbf{1 0 0 - S W} & \text { S.C.Y } & \text { GOT\% } \\ \text { Rep } & 2 & 142.9 & 40.825 & 0.12111 & 13.23 & 0.00173 & 0.9775 & 199811 & 2.518 \\ \mathrm{Sd} & 5 & 19567.7^{* * *} & 585.446^{* *} & 0.13333^{\text {ns }} & 1110.38^{* *} & 0.08948^{*} & 2.2407^{\text {ns }} & 2.20 \times 10^{7 * *} & 34.054^{* *} \\ \text { Error Rep } \times \mathrm{Sd} & 10 & 119.0 & 54.435 & 1.03889 & 69.69 & 0.03253 & 2.2088 & 719239 & 16.055 \\ \mathrm{CV} & 2 & 271.7^{* *} & 17.513^{\text {ns }} & 1.23111^{\text {** }} & 78.18^{* *} & 0.09901^{* *} & 4.7721^{* *} & 1037794^{*} & 25.529^{*} \\ \mathrm{Sd} \times \mathrm{Cv} & 10 & 45.4^{\text {ns }} & 31.847^{\text {ns }} & 0.68889^{\text {ns }} & 10.94^{\text {ns }} & 0.00952 & 2.6506^{\text {ns }} & 50915.4^{\text {ns }} & 10.577^{\text {ns }} \\ \text { Error Rep } \times \operatorname{Sd} \times \mathrm{Cv} & 24 & 173.5 & 14.573 & 1.96000 & 92.10 & 0.06300 & 5.7344 & 1696195 & 27.033 \\ \text { Total } & 53 & 20320.1 & 871.639 & 5.17333 & 1374.51 & 0.29528 & 18.5841 & 2.574 \times 10^{7} & 111.034\end{array}$

Means sharing different letters differ significantly at $p \leq 0.05$. Significant changes are highlighted by an asterisk (*); $P \leq 0.05, * * 0.01 n$, non-significant. "PH: plant height (cm); Sympod: sympodials; monopod: monopodials; O.B: opened boll; ABW: Average boll weight (g); 100SW: 100-seed weight (g); S.C.Y: Seed cotton yield $\left(\mathrm{kg} \mathrm{ha}^{-1}\right)$ and GOT\%: Ginning out turn.

100-cotton seed weight $(g)$

Cultivars showed incredible changes for 100-cotton seed while planting dates and connection were discovered immaterial. The highest estimation of 100 -cotton seed weight (7.24g) was seen in $\mathrm{MNH}$ 886 that was measurably at standard with $\mathrm{BH}-184$. The mean value for cultivars i.e.BH-184, $\mathrm{MNH}-886$ and CIM-598 were 7.02, 7.24 and 6.52g, individually (Table 3). It has been accounted for that 100-seed weight essentially contrasted by various cultivars. Bilal et al. (2019) likewise found that cultivars had altogether influenced by cotton seed weight. Arshad et al. (2007) likewise detailed that planting dates and cultivars strikingly altered for 100 -cotton seed weight. These outcomes are predictable with the after effects of Hebbar et al. (2007) and Bilal et al. (2019).

Seed cotton yield $\left(\mathrm{kg} \mathrm{ha}^{-1}\right)$

The information in Table 3 uncovered that seed cotton yield considerably varied with various planting dates and cultivars while the interaction was found nonnoteworthy. Greatest seed cotton yield was gotten on April 30 followed by April 15, May15and 30, June 14 and 29 individually. The mean value of seed cotton yield for various planting dates was 3265.83, 3681.09, $3310.83,2871.68,2236.6$ and $1851 \mathrm{kgha}^{-1}$ separately. Higher seed cotton yield was produced from the prior planted cotton crop (Bilal et al., 2019). Planting of cotton from ahead of schedule to mid of May gave more seed cotton yield (U1lah et al., 2019; Bilal et al., 2019; Rahman et al., 2019).

Seed cotton yield unmistakably differed with different cultivars and highest seed cotton yield was produced by $\mathrm{MH}-886$ that was factually at with $\mathrm{BH}-184$. The mean estimation of seed cotton yield for various cultivars for example BH-184, MNH-886 and CIM598 were $2867.8,3040.05$ and $2700.5 \mathrm{kgha}^{-1}$. Rahman et al. (2016) announced that seed cotton yield was essentially varied by various planting dates and May 
planting of cotton delivered most extreme yield when contrasted with April and July planting. It has been accounted for that cultivars and planting dates have fundamentally influenced seed cotton yield and their association additionally indicated critical outcomes. In late planting of cotton and the yield was diminished because of a brief period for fruiting than typical planting of cotton (U1lah et al., 2019; Bilal et al., 2019; Rahman et al., 2018).

\section{Conclusions and Recommendations}

Cotton cultivars grown before April 15 demonstrated late germination with feeble seedlings. While the cultivars planted in the mid season for example April 30 demonstrated ideal production in dry atmosphere of Bahawalpur. Though later planting of cotton during extraordinary hot conditions of June influences adversely both the yield just as phenology of the harvest. Also, unique cotton varieties showed various yields relying upon their genetics qualities under different atmosphere settings. For dry atmosphere MNH-886 planted on April 30 outflanked than different cultivars.

\section{Novelty Statement}

Cotton is a major field crop and it is cultivated for fiber and oil purpose. There are lot of studies on late sowing of cotton but very rare on early sowing of cotton and with different cultivars.

\section{Author's Contribution}

KMRM, RI, MI, UR, got the idea, managed overall article development, collected observed data. MHR, FA, AN, MS, gave specialized support, facilitated the experimental work provided supervisory help at every phase of research. JS, AW, MTK, MA organized write-up and performed data analysis as well as offered technical writing assistance.

\section{Conflict of interest}

The authors have declared no conflict of interest.

\section{References}

Ali, H., D. Muhammad, M.N. Aftzal and S.A. Abid. 2005. Seed cotton yield of different cultivars as affected by sowing time under agroclimatic conditions of southern Punjab. Indus
Cotton, 2: 186-189.

Ali, M., Q.M. Din, M.A. Ali, S. Sabir and L. Ali. 2004. Cotton yield as influenced by different sowing dates under the climatic conditions of Vehari-Pakistan. Int. J. Agric. Biol., 6: 644-646.

Arshad, M., A. Wajid, M. Maqsood, K. Hussain, M. Aslam and M. Ibrahim. 2007. Response of growth, yield and quality of different cotton cultivars to sowing dates. Pak. J. Agric. Sci., 44: 208-212.

Bange, M.P. and S.P. Milory. 2000. Timing of crop maturity in cotton. Impact of dry matter production and partitioning. CSIRO. Plant Ind. Austral. Cotton Cooper. Res. Centre, Field Crops Res., 68: 143- 155. https://doi. org/10.1016/S0378-4290(00)00116-7

Bilal, A., A. Ahmad, F. Rasul and G. Murtaza. 2019. Optimization of the sowing time for Bt cotton production in Punjab, Pakistan. Pak. J. Agric. Sci., 56: 95-100.

Bozbek, T., V. Sezner and A. Unay. 2006. The effect of sowing date and planting density on cotton yield. J. Agron., 5: 122-125. https://doi. org/10.3923/ja.2006.122.125

Ehsan, F., A. Ali, M.A. Nadeem, M. Tahir and A. Majeed. 2008. Comparative Yield Performance of New Cultivars of Cotton (Gossypium hirsutum L.). Pak. J. Life Soc. Sci., 6: 1-3.

Gardner FP, Pearce RB, Mitchell RL. 1985. Physiology of crop plants. Scientific Publisher, $2^{\text {nd }}$ ed. Iowa (Ames, USA). pp. 200-205.

Godoy, S., 1994. Comparative study of earliness estimators on cotton (Gossypium birsutum L.). ITEA (Informacion Tecnica Economica Agraria). Produccion Vegetal (Espana).

Govt. of Pakistan. 2018. Economic survey of Pakistan 2018, Ministry of Food, Agric. and Livestock, Economic wing, Islamabad, Pakistan. pp. 16-18

Hebbar, K.B., N.K. Perumal and B.M. Khadi. 2007. Photosynthesis and plant growth response of transgenic Bt cotton (Gossypium hirsutum L.) Hybrids Under Field Condition, Photosynth. 45: 254-258. https://doi.org/10.1007/s11099007-0041-1

Iqbal, J., 2010. Modeling the impact of climate change on seed cotton (Gossypium birsutum L.) yield in Punjab, Pakistan. Doctoral dissertation, University of Agriculture, Faisalabad Pakistan.

Iqbal, R., M.A.S. Raza, M.F. Saleem, I.H. Khan, S. Ahmad, M.S. Zaheer, M.U. Aslam, I. Haider. 
2019. Physiological and biochemical appraisal for mulching and partial rhizosphere drying of cotton. J. Arid Land., 11: 785-794. https://doi. org/10.1007/s40333-019-0014-9

Muhammad, D.M., M. Anwar, M.S. Zaki and M.N. Afzal. 2002. Effect of plant population and nitrogen variables on cotton crop. Pak. Cottons, 47(1-2): 37-41.

Nawaz, B., M. Naeem, T.A. Malik, G. Muhae-UdDin, Q. Ahmad and S. Sattar. 2019. A review about cotton leaf curl viral disease and its control strategies in Pakistan. Int. J. Inn. Appl. Agric. Res., 3: 132-147. https://doi.org/10.29329/ ijiaar.2019.188.13

Panhwar, G.N., A.R. Soomro, R. Anjum, S.B. Babar, A.M. Memon and A.W. Soomro. 2002. Predicting earliness in cotton during crop development stage-11. Asian J. Plant Sci., 1: 3738. https://doi.org/10.3923/ajps.2002.37.38

Rahman, M.H., A. Ahmad, A. Wajid, M. Hussain, J. Akhtar, G. Hoogenboom. 2016. Estimation of temporal variation resilience in cotton varieties using statistical models. Pak. J. Agric. Sci., 53: 169-186. https://doi.org/10.21162/ PAKJAS/16.4549

Rahman, M.H., A. Ahmad, X. Wang, A. Wajid, W. Nasim, M. Hussain and M. Awais. 2018. Multi-model projections of future climate and climate change impacts uncertainty assessment for cotton production in Pakistan. Agric. For. Meteorol., 253: 94-113. https://doi. org/10.1016/j.agrformet.2018.02.008

Rahman, M.H., A. Ahmad, A. Wajid, M. Hussain, F. Rasul, W. Ishaque, M.A. Islam, V. Shelia, M. Awais, A. Ullah, A. Wahid, S.R. Sultana, S. Saud, S. Khan, S. Fahad, M. Hussain, S. Hussain and W. Nasim. 2019. Application of
CSM-CROPGRO-Cotton model for cultivars and optimum planting dates: Evaluation in changing semi-arid climate. Field Crops Res., 238: 139-152. https://doi.org/10.1016/j. fcr.2017.07.007

Reddy, K.R., G.H. Davidonis, A.S. Johnson and B.T. Vinyard. 1999. Temperature regime and carbon dioxide enrichment alter cotton boll development and fiber properties. Agron. J., 9: 851-858. https://doi.org/10.2134/ agronj1999.915851x

Sarwar, M., M.F. Saleem, M.A. Wahid, A. Shakeel and M.F. Bilal. 2012. Comparison of $\mathrm{Bt}$ and non-Bt cotton (Gossypium hirsutum L.) cultivars for earliness indicators at different sowing dates and nitrogen levels. J. Agric. Res., 50(3): 03681157.

Steel, R.G.D., J.H. Torrie and D.A. Dickey. 1997. Principles and Procedures of Statistics: A Biometrical Approach. $3^{\text {rd }}$ ed. McGraw Hill, New York, USA. pp. 352-358.

Steglich, E.M., T.J. Gerik, J. Kiniry, J.T. Cothern, R.G. and Lemon. 2000. Change in light extinction coefficient with row spacing in upland cotton. Proceedings Belt wide Cotton Conferences, San Antonio, USA, 4-8 Jan, 1: 606-608.

Tahira, J., H. Abro., A.S. Larik and Z.A. Soomro. 2007. Performance of different cotton Cultivars under the climatic conditions of Jamshoro. Pak. J. Bot., 39: 2427-2430.

Ullah, N., N.U. Khan, A.A. Khakwani,M.S. Baloch, E.A. Khan, F. Khan and Z. Ullah. 2019. Impact of sowing time on yield and fibre of bt. cotton varieties in arid environment of Dera Ismail Khan. Sarhad J.Agric., 35: 264-273. https://doi. org/10.17582/journal.sja/2019/35.1.264.273 